\title{
Reproducing the City of London's institutional landscape: the role of education and the learning of situated practices by early career elites
}

\section{Please cite as:}

Faulconbridge JR. Hall S (2014) Reproducing the City of London's institutional landscape: the role of education and the learning of situated practices by early career elites. Environment and Planning A 46, 1682-1698

\section{Abstract}

In this paper, we argue that postgraduate education forms an important, but hitherto neglected, element in the distinctive institutional landscape of the City of London. In particular, and drawing on research into early career financial and legal elites in the City, we show how postgraduate education tailored to the demands of employers within London plays an important role in indoctrinating early career elites into situated, City-specific working practices, and, in so doing, helps to sustain the City's cultures and norms of financial practice. Specifying the role of postgraduate education in reproducing these situated City practices is significant because, although geographical variegation in working practices between international financial centres has been widely reported, less attention has been paid to how such institutionally embedded differences are created and sustained. By identifying education as one mechanism of creation and sustenance, our analysis enhances understanding of how the institutional landscapes that underlie financial centres might be maintained or when necessary challenged; the latter being significant in relation to attempts to reform practices and cultures in international financial centres in the wake of the $2007-8$ crisis.

Keywords: Institutions; financial centres; City of London; elites; education; practice 


\section{Introduction}

Since Amin and Thrift's $(1992,1995)$ interventions, there has been significant interest in the institutional underpinnings of international financial centres such as the City of London (Clark et al., 2002; Clark and Wójcik, 2007; Faulconbridge et al., 2007). In parallel, a significant body of work has developed on elites in finance (see for example, Augar, 2001), often drawing inspiration from mid twentieth century studies such as those by Mills (1956). Moreover, a number of more recent contributions (Daloz, 2010; Savage and Williams, 2008), inspired by the financial crisis (Engelen et al., 2012; Tett 2010), serve to re-emphasise the need for 'a reengagement with fundamental questions about elites and the organizational infrastructures they operate in' (Zald and Lounsbury, 2010: 964). However, the relationships between financial elites, their practices, and the institutional underpinnings of financial centres have received limited attention. In this paper, we advance understanding of such relationships by analysing the relatively neglected role of various forms of education in reproducing elite practices in times of economic stability and crisis. In particular, we consider how such education is both defined by and helps reproduce the institutions of a financial centre.

In order to develop our arguments theoretically, we draw on theories of practice to better understand the social structuring of situated and normalised economic practice (Gherardi, 2009; Jones and Murphy, 2011; Shove 2003; Wenger 1998). Using this literature, we highlight how post-first degree education represents an important means by which early career elites are inculcated into the place and organisationally 
specific meanings, competencies and technologies associated with financialised business practices in the City of London. This theoretical basis for analysis is operationalized through original qualitative data generated by interviewing elites working in the City of London's financial (investment bankers) and producer service (lawyers) complex.

Our analysis of education is significant because, whilst research has demonstrated that the practices of elites are shaped by the institutional and cultural contexts - or 'worlds' in the language of MacKenzie (2003) - in which they operate (Ho [2009]; Lounsbury [2011]; Zaloom [2006]), limited attention has been paid to the mediating mechanisms that render institutions effective in the sense of shaping the practices of elites. There has also been little attention to how, in turn, such mechanisms can help sustain institutions themselves. We show here that postgraduate education represents one important mechanism for effecting and sustaining the institutional and cultural landscape of London's international financial district. This suggestion is noteworthy in two ways. First, it suggests that education is an important way that the well-documented (see Brenner et al., 2010; Clark and Wójcik, 2007; Dixon, 2011; Engelen et al., 2010; Faulconbridge and Muzio, 2009) variegation within the international financial system is reproduced, and that education may therefore also have played an important role in facilitating and legitimating the cultures of work that underlay the financial boom of the 2000s in London and the ensuing crisis. In turn, second, the suggestion that education sustains London's institutionalised financial culture implies that attempts to reform the working practices and cultures in the wake of the 2007-8 financial crisis (for example, The Turner Review 2009) 
need to pay greater attention to the ways in which distinctive institutional landscapes emerge and are reproduced; the role of education in shaping the situated practices of elites being an exemplary reproductive mechanism that, when studied, reveals the wider importance of more thoroughly analysing the multi-level architectures through which institutionalised norms are not only sustained but also potentially challenged and changed.

We develop this argument over six sections. Next we draw on social theories of practice in order to conceptualise the role of postgraduate education in inculcating new recruits into legitimated forms of elite work, and to tease out the role of this education in the reproduction of the institutional landscape of the City of London. In sections three, four and five respectively we use this conceptual framing to interpret empirical material that documents: the nature of postgraduate education in the case of financial and legal services in the City of London; its role in shaping elite practice; and the co-constitutive relationship between education and the institutional landscape of London's financial district. We consider the implications of our analysis in the concluding section of the paper.

\section{The City, institutions and education}

The City of London's pre-eminence in international finance has, in various ways, been explained in existing literatures through reference to institutional effects. By considering both the formal dimensions of institutions - the regulatory regime governing the city, most notably exemplified by the effects of big bang - but also the interdependent social and cultural norms that underlie accepted practice - 
exemplified by Augar's (2001) analysis of the death of gentlemanly capitalism post big bang - studies have revealed that the competitiveness of the City is fundamentally based on an advantageous institutional regime (Clark, 2002; Clark and Wójcik, 2007; Faulconbridge, 2007; Faulconbridge et al., 2007; Leyshon and Thrift, 1994; Knox-Hayes, 2010; Kynaston, 2002). Amin and Thrift $(1992,1995)$ thus conclude that an 'institutional thickness' sustains the global network capacity of the City.

Analysis of the City's institutional foundations relates to an extensive body of literature that examines the way institutions generate globally competitive regions (Saxenian, 1994; Storper, 2011), but also potentially lock some regions into trajectories of economic decline (Grabher, 1993; MacKinnon et al., 2009). In this literature, the evolution of institutions is a significant concern (Boschma and Frenken, 2006; Martin, 2010; Storper, 2009), receiving attention across the social sciences in relation to broader questions about varieties of capitalism (Crouch, 2005; Streeck, 2009; Thelen, 2004). Yet, in the geographical literature, until recently, comparatively little attention has been paid to the mechanisms that create and sustain institutions, with research instead being focused on characterising the institutional regimes that are associated with different regions (Gertler, 2010). In contrast, work on the varieties of capitalism places emphasis on the way institutions are (re)produced through mechanisms including labour /industrial relations, governance regimes, and of especial interest in the context of this paper training and education systems. As interest in institutional change has grown in geographical literatures, the limited analysis of the mechanisms of institutional creation, 
maintenance and change has begun to be corrected, for instance through a focus on the role of transnational migrants (Hatch, 2013), corporations (MacKinnon, 2012) and professional associations (Benner, 2003; Faulconbridge, 2007). However, understandings of the mechanisms through which the institutions of economies like the City of London are created, sustained and potentially disrupted remain limited.

Developing such an understanding is particularly important in relation to the City because of concerns about how institutions underlie the continued geographical variegation in financialised capitalism (see Brenner et al., 2010; Clark and Wójcik, 2007; Dixon, 2011; Engelen et al., 2010; Faulconbridge and Muzio, 2009), and may also promote more or less sustainable forms of financial practice. Most notably, the institutional landscape of the City has been scrutinised because of the ways in which it may have facilitated and legitimated the calculative practices of elites that were central to the innovations in the boom of the 2000 s that ultimately triggered the crisis of 2007-8 (Tett 2010). This work emphasises how the expertise of economic elites emerges, in part, through the organisational and place specific contexts in which they work; Zald and Lounsbury (2010: 972) suggesting these contexts result in elites 'embedded in networks of relationships', the 'normative/cognitive expectations of relevant environmental actors constrain[ing] and demand[ing] organizational action'. However, whilst such work identifies the institutions of financial centres as being important in shaping the nature of geographically variegated financial practice, limited attention has been paid to how such contexts become effective in the first place and are sustained (or challenged and changed) over time. In response, in this paper, we consider how education may act as one of 
the mechanisms through which the institutions of the City, and in particular the social and cultural dimensions of institutions, are rendered effective and sustained.

The education-institutions-practice nexus - a conceptual frame

We are not the first to suggest a connection between education, institutions and economic practice. As already noted, literatures identify the regulation of training and education as a fundamental factor sustaining nationally distinctive varieties of capitalism (Hall and Soskice, 2001; Thelen, 2004). Calori et al. (1997: 684) develop this idea, emphasising that education is effective because schools 'communicate the dominant views of culture (implicit knowledge of values, beliefs, and views of social order)'. In making this connection, Calori et al. (1997) begin to identify the link between education and the (re)production of the regulatory and social and cultural dimensions of institutions. We develop this approach here through Bourdieu's and other's work on social practice in order to reveal how education plays an important role in sustaining the social and cultural dimensions of the City's distinctive institutional environment; inculcating financial elites into legitimated forms of practice within the City that both shape and are shaped by the City's institutional environment.

For Bourdieu $(1990,1996)$, every field (a field being a recognised socio-spatial arena delimited by regular interactions between different actors) is characterised by a series of assumptions and expectations about appropriate everyday practice practice being everyday sayings and doings (Schatzki, 1996: 89). We conceive of the City of London and its producer service complex as a field because of the 
documented regular interactions, as part of collaborations that enable financial deal making, between the individuals working in the different finance and producer services in the City (Faulconbridge and Muzio, 2009; Knox-Hayes, 2010; Sassen, 2012). These interactions have been shown to produce a particular set of norms, values, expectations and associated practices that are tied to the City's distinctive culture (Amin and Thrift, 1992, 1995; Augar, 2001; Cook et al., 2012; Hanlon, 2004). To hold a legitimate position in the City field an individual must, therefore, be inculcated into and perform the practices associated with the field. This raises a key question underlying our analysis: what role does postgraduate education play in ensuring the cultures and practices of new elites correspond with what is deemed legitimate in the City field, and how does this role exemplify the significance of education as a means of rendering effective, sustaining and possibly challenging Cityspecific institutions? Social theories of practice that have emerged from disciplines including economics, geography, management and sociology (see Gherardi, 2009; Jones and Murphy, 2011; Reckwitz, 2002; Røpke, 2009; Shove, 2003; Wenger 1998; Wilk, 2002) and which build on Bourdieu's work provide some further theoretical scaffolding which is helpful in addressing these questions.

In particular, Shove et al. (2012) identify three elements that produce and sustain practices. First, practices involve using certain kinds of materials or technologies. This can range from large objects such as a car or computer through to more mundane objects such as a spread sheet (see MacKenzie, 2006 on the centrality of financial models in financial practice). Importantly, the way that such technologies get deployed in practices results from the two other elements of practice that Shove 
et al. (2012) focus upon. Second, meanings relate to the way that a series of cultural and emotional states are effective in that the doing of a practice becomes a way of fulfilling particular desires and complying with understandings of normal, needed or valuable action. As such, the doing of a practice takes on symbolic status, most notably because it indicates that an individual is behaving legitimately in any particular field (Wenger, 1998). However, in order to perform a practice, the third dimension identified by Shove et al. (2012) - competencies - are also required. These come both in the form of explicit knowledge of the rules and procedures that dictate how a practice should be performed, but also embodied know-how and skill relating to everything from how to physically carry out a practice (how to dress, comportment, the corporeal skill involved in using an object), through to how to interact with and respond to others performing the same or an alternative practice. Combined, meanings and competencies thus dictate how a particular technology is put to work in everyday practice as part of the fulfilment of a set of social norms.

By focussing on the three elements of practice it becomes clear that performers of a particular practice must 'possess' certain values, emotions and logics as well as skills and knowledges, in order to render a practice attractive (i.e., to recruit them to the practice) and achievable. Without such 'possessions' an individual will lack the motivation and capability to become a legitimate practitioner. Of particular importance for our interest here in institutions-education-practice linkages, studies have shown that the places and spaces in which individuals dwell and learn are pivotal in determining whether an individual is recruited to perform a practice. By 
drawing on the work of Pred (1981) on life paths and projects, it has been argued that:

"there is a strong element of path dependency in daily life: the engagement in practices and projects throughout life leaves accumulated sediments in the mind and body of individuals, opening for participation in some practices while excluding others" (Røpke, 2009: 2493).

The 'sediments' alluded to in this quotation relate to how experiences embed in individuals particular meanings and competencies that attract them to, and enable them to perform legitimately a practice. Without these sediments recruitment would not happen (the individual would not value the practice and/or be capable of performing it). This work on sediments is significant for our argument because it indicates that, alongside the school and university education histories that have been well-documented as influences on an individual's practices (see Brown and Hesketh 2004; Bourdieu, 1996; Calorie al., 1997; Waters 2007), experiences in postgraduate education help recruit new elites to certain practices associated with work in financial centres by leaving 'sediments' that are not established in earlier educational experiences.

A practice perspective suggests it is, therefore, fruitful to ask how postgraduate education helps individuals learn about meaning and competency and associated practices and how such learning is situated and associated with practices that are field-specific, in turn both being shaped by and shaping the institutional environment in which the individual is working. In particular, the framework 
provided by practice theory leads us to ask the following questions about the role of postgraduate education in (re)producing the institutional environment of the City of London: in what ways does postgraduate education seek to generate particular values, priorities, passions or logics (i.e. meanings)? What rules, procedures, and tacit and embodied know-how (i.e., competencies) are learned through the educational techniques adopted? How is learning influenced by and a tool for sustaining the already existing institutions of the City? What are the implications of understanding the connections between education, institutions and practices for attempts to disrupt institutions and their effects? Responding to such questions is the focus for the rest of our analysis.

\section{Opening the black box of early career elite education in the City of London}

The centrality of both financial and legal firms to the producer service complex economy of the City of London is well documented (Beaverstock et al., 2000; Sassen, 2012). Indeed, both finance and professional services were at the heart of the period of rapid finance led growth and innovation in the City during the 2000s (Engelen et al., 2010; Froud et al., 2006). For example, the rise of securitisation saw the growing enrolment of professional services, notably corporate law firms, into the international financial system and a far greater role for elites with a finance rather than general management background (Faulconbridge and Muzio 2009; Zald and Lounsbury, 2010). This provides the rationale for the empirical focus in this paper on elites in the financial and legal services sector in the City of London. The analysis below is built upon in-depth original empirical study of the two sectors with both semi-structured interviewing and supplementary observational study used to unpack 
the forms, function and characteristics of postgraduate education. In the case of finance, a total of 90 interviews were completed with: investment bankers at a range of career stages working in London to discuss their postgraduate education and training (38 interviews with UK and non-UK nationals); business school lecturers and managers (36 interviews); human resource managers in investment banks in London (6 interviews); and educators and managers in for-profit financial business education and charitable organisations in the UK (10 interviews). This interview data was complemented by 6 hours of observation conducted in financial analysis classes in business schools. Similarly, in the case of law a total of 43 interviews were completed with a combination of: senior representatives of major corporate law firms in the City including their training departments (the latter group totalling 19 interviews); for-profit providers of education to law firms in the City (11 interviews), regulators of the compulsory elements of postgraduate education (3 interviews); and early career lawyers experiencing postgraduate education (10 interviews). Observation of postgraduate training courses totalling 6 hours was completed. For the purposes of this paper, coded datasets were compared to identify common themes and exemplary cases that reveal the points of similarity in the role of postgraduate education in (re)producing elite practices. In the analysis below, all quotations are anonymised and a description provided of the identity of the respondent making the reported comments. Data from the two studies is used not to develop a comparative case study but to reveal key and common processes and outcomes associated with the production of situated practices through postgraduate education. 


\subsection{Key features of postgraduate finance and legal education}

Once the initial barriers to entry have been negotiated, a process which in itself continues in a revised form to rely upon the possession of certain educational credentials to signify both technical and social competency (Ashley, 2010; Cook et al., 2012; Hall and Appleyard, 2011), for those entering the elite occupations of finance and law in the City of London the completion of firm-based postgraduate education is a central part of gaining legitimacy in the field. Table 1 outlines the characteristics of this education in finance (investment banking specifically) and law (corporate law in particular). Table 1 reveals how the two fields share two important and common characteristics in terms of postgraduate education.

First, in both sectors firm-based postgraduate education is associated with developing key technical competencies, something which ensures legitimacy is gained in terms of regulatory approval to operate in the field. In order to practice as a financier in London, at the time the this research was conducted an individual had to demonstrate that they were 'competent' as defined by the Financial Services Authority (FSA) (see below for a discussion of the regulatory changes in the City following the dissolution of the FSA in April 2013). 'Competency' as defined by the FSA could be achieved by: acquiring a set of credentials from the list of FSA of Financial Services Skills Council 'appropriate examinations'; and/or by demonstrating experience of undertaking particular tasks, something assessed through observation by senior colleagues and mentoring. In law, the regulatory stage is associated with education mandated for all lawyers in England and Wales - the Legal Practice Certificate (LPC). As noted in Table 1, in the case of those studied as part of the 
research reported here, mandated qualifications were gained by completing a course designed specifically for City lawyers (the City LPC).

Second, table 1 also reveals that in both finance and law various forms of additional and strategically designed education are provided to new recruits throughout the early stages of their career in order to pass-on best practice to the younger generation. The specific nature of this education is detailed in our analysis below. There are subtle differences in this continuing education between the sectors. For instance, those entering the City legal field must complete a mandated number of hours of continuing professional development whereas such training is optional (although considered best practice) in finance. We are not, then suggesting that the practices new elites learn about in the two occupations are identical; whilst there are commonalities due to the two occupations both existing in the City's producer service complex, each industry also has specificities in terms of technical competencies and tacit cultures. Nonetheless, table 1 clearly shows that both finance and law have well-developed processes of postgraduate education, with clear pathways that new recruits must follow. The analysis below examines how these common educational processes reproduce the City's institutions.

[Insert Table 1 here]

\section{Education and the process of learning the practice of a City elite}

Following the logics of social theories of practice, in this section we examine how the postgraduate education detailed in table 1 performs an important role in inculcating 
individuals into elite practice in the City. Beginning with competencies, postgraduate education provides an important avenue through which the technical know-how and basic competencies required to work in the City can be disseminated to early career elites. This is important because in both finance and law undergraduate education is not assumed to necessarily provide the technical training needed for a career in the City. As one interviewee noted:

At the beginning stage, it's the technical experience, the technical grounding that we do ... it is very broad, it's quite theoretical as well. You don't get the experience of actually applying it (Analyst, investment bank, City of London)

In investment banking, this substantive knowledge base increasingly focuses on quantitative analysis techniques that underpin securitised financial products. This reflects the growing importance of debt structuring and arranging within contemporary investment banking business models as opposed to the emphasis on mergers and acquisitions that typified the industry until the 2000s (Augar, 2001; Lewis 2011). Indeed, the value attached to these foundational competencies and knowledges by investment banks is reflected in the handbook accompanying the training program for new recruits at Goldman Sachs, the handbook arguing that 'a deep understanding of our products and markets is critical to your ability to innovate and create new solutions' (Goldman Sachs, 2012). In law the substantive knowledge base relates to codified procedures and precedent-based 'black letter' law - i.e., the fundamental principles underlying the legal structuring of common types of transaction. Fundamental technical know-how and competency to use (and know 
how not to use) a particular instrument is important because it provides the foundations for effective practice.

It was very clear in interviews, however, that training focussed on explicit rules and relating to the technicalities of particular instruments was viewed by many as being only the beginning of the process of inculcating new recruits into life in the City. One individual responsible for training in a City law firm described the technical part of the training he organised as 'frankly checking the regulatory boxes. So in order to get stuff out of the way we do run some of the compulsory programmes' (Head of training and education, global law firm based in London). The phrase 'getting stuff out of the way' is significant as it is indicative of the value placed on dedicated time for training that deals with more tacit and embodied forms of learning; this being learning about what theories of practice refer to as the meanings associated with a practice. Such training is designed to shape the practical action involved in deploying financial and legal instruments in any market situation. Such expertise relates less to written down rules and more to the rationales lying behind the way particular instruments are put to work, particularly to ensure a practitioner's legitimacy in the eyes of clients and competitors. As two interviewees put it:

there is also quite a lot of time dedicated to them instilling and communicating the values of the company and what is going to be expected of people and giving guidance onto the key values, what it means to be professional, what the standards are, and what you are expected to project on a day to day basis so yes quite a lot of time is spent on that in the beginning. I think people expect that ....but a lot of time 
is given at the beginning to get people in through the door (Investment bank vicepresident, City of London)

I would personally say that that [technical training] doesn't necessarily make you a good lawyer just looking at a particular page and being able to recount stuff. I think generally in the professions there is an understanding now that there is a balance between technical skills, technical knowledge, and the skills to deliver that in a real life setting (Head of training and education, regulatory body for legal industry)

Indeed, in the case of law the $P$ in the LPC is highly significant, emphasising the importance of learning the practice of law and not just about the law. The emphasis placed on learning about practice in postgraduate education in the City corresponds with the arguments made in the wider literature about the role of education in learning to perform professionally (Anderson-Gough et al., 2000; Faulconbridge et al., 2012) where it has been highlighted that in firms' training programmes technical competence receives far less attention than learning about and displaying culturally legitimate practice. Indeed, reflecting this, in the case of early career investment bankers, developing understanding through postgraduate education of the tacit meanings associated with the pervasive discourse of client service is particularly important; early career elites being expected to quickly develop a predisposition towards certain legitimated practices through awareness of their symbolic meaning (Hall, 2013). One interviewee began to summarise this situation by highlighting how: You obviously need the theoretical background but something I've always experienced is that you have a theoretical background in something so principled, you have the technical professional in a particular issue but it is almost impossible to 
remember that without the practical application as well. So I think they need to be very closely aligned and you can't really have one without the other - things that are really important in the workplace like presentation skills, soft skills, knowing how to approach a client and how to address them (Investment bank president, City of London, emphasis added)

The use of the term 'principled' is particularly significant in this quotation and alludes to the importance of meanings in guiding how individuals deploy legal or financial materials - financial models, legal precedents etc.

Training is not, however, intended to be restricted to the specifics of the particular financial or legal instrument studied in the classroom. One of the defining features of financial and producer service work in the City is its bespoke nature; advice to clients needing to respond to their particular commercial imperatives. This means those delivering advice tend to work in relatively autonomous ways and are expected to use their judgement to decide how to best respond to a client's needs (Alvesson, 2001; Faulconbridge and Muzio, 2008). Hence training can never cover all of the possible situations a new recruit working in finance or law may find themselves in. The spaces of learning created are, therefore, designed to instil a broad set of meanings that, when established as sediments in the psyche of individuals, will shape the practice of financial or legal work in whatever situation arises. I.e., the training is designed to develop a set of meanings that shape all action, with competencies allowing this action to be successful completed. 
Training for new recruits in the City forms, then, an important element in inculcating new recruits into legitimate forms of practice within London's financial district thanks to the learning it allows about both the meanings and competencies associated with such practice. This reflects the suggestion of Calori et al. (1997) that education has an important role in sustaining institutionalised cultures. Whilst this finding is in many ways not surprising, it is an important one because of the wider neglect of postgraduate education in extant accounts of the formation and reproduction of financial centre specific working practices. In particular, to use the language outlined in the theoretical discussion of practice above, it might be said that postgraduate education, as part of the life path of new recruits, helps create the 'sediments' (Pred, 1981; Røpke, 2009) which predispose individuals to become recruited to the established practices of the City. Moreover, in the remainder of the paper, we argue that the role of postgraduate education in producing these sediments needs further analysis because they are shaped by a co-constitutive relationship between education and the City specific institutional context; a finding that has important implications for understanding of the role of education in contributing to the continued variegation within the international financial system of both institutions and practice.

\section{Education and the reproducing the City's institutionalised culture of practice}

Whilst the analysis above might be read as showing how postgraduate education inculcates early career elites into the competencies and meanings associated with the 'global language of finance' (Clark, 2011) and 'transnational legal arenas' (Trubek et al., 1994), it is important to note that these languages and arenas are 
geographically variegated (Clark and Wójcik, 2007; Dixon, 2011; Ho, 2009;

Lounsbury, 2011; Zaloom, 2006) and that the postgraduate education provided in the City both reflects this variegation and reproduces it. This variegation became most clear when those we studied sought to work in other financial centres, during job rotations organised as part of career development programmes, or when an individual independently decides to relocate. This reflects previous studies of the inherently geographical and sticky nature of elite work (Beaverstock and Hall, 2012; Beaverstock, 2005; Faulconbridge et al., 2009). In this respect, early career elites often find that the situated practices learned in London do not necessarily transfer to another financial centre. For instance, one lawyer described how he had found his approach to legal work completely inappropriate when spending a period of time in Madrid, Spain. He described how:

when I was there, I said, what would you do if a client sued you? And the lawyer nearly fell out of his chair and said, "I would strike him off my list of clients"...they are more like, I'm the lawyer, I'm their friend, I help families in difficulties, blah, blah. You know, I mean a more paternalistic lawyer and they're not going into the big business deals and financial wizardry and stuff (Lawyer and education provider)

Similarly, a financier in the City noted how:

After my initial training in New York, I was then sent on I think 6 rotations where I was working for a short period in different functions globally. It was all about learning through doing, getting a feel for the working culture, the hours, the dress, how you handle clients and of course colleagues. But that wasn't just in London even through that is where I work now (Investment bank vice-president) 
The production of such geographical specificity through postgraduate education can be explained in two interrelated ways that reveal the ways in which City specific institutions affect post-graduate education. First, those designing and delivering education do so in a way that is intended to reflect and thus sustain the already existing institutional norms and cultures of the City. Specifically, individuals already inculcated by the institutions of the City become key educators and actors who ensure institutions are effective and sustained. Of particular importance in this regard is the use of simulations in postgraduate education. Influenced by the wider pedagogic literature on problem based learning (Boud and Feletti, 1997), simulations tend to be designed by for-profit education providers specialising in training new elites in the City, but the training event itself relies heavily on the involvement of active practitioners from the companies employing the new elites. The role of active practitioners is important because they bring to the training forms of tacit understanding relating to the rules of the game in the City, and in particular an understanding of the expectations of clients and other elites in the City field. Specifically, by simulating client-facing situations using senior employees of finance and law firms, as well as actors who have had a career in the City and who often play the role of the client, education providers are seeking to generate opportunities for learning about meanings and competencies associated with legitimate practice. Such learning occurs through combinations of observation (of actors, senior professionals) and critical feedback (provided afterwards about an individual's performance in the simulation). As one CEO of a for-profit legal education provider noted:

the structure of our LPC is around client simulations. So for example, the students encounter 3 major clients in the first part of the programme [...] and it is through 
those three major clients that the compulsory subjects of business law, property law and litigation are delivered. For example, the first major client they meet is a supermarket PLC [...] So they get a huge amount of information about this client, they meet the directors, I mean it is all fictional, but it is simulated. At the end of the compulsory stage [...] they do a transaction which is essentially a [...] due diligence exercise, using a virtual data room, looking at litigation, commercial property and business issue. They then have to do a presentation to a tutor who's playing the client.

This quotation reveals that the most effective training seeks to provide spaces of experience in which individuals come to value particular practices; these being the practices that the City's already institutionalised norms and cultures define as valuable and as a source of legitimacy. For instance, in relation to the way particular instruments should be put to work in the client's best interests one interviewee noted:

what we're doing is, we're getting students to revisit these basic concepts, so in business law, we're getting them to look at contract law but in most cases in a much more practical context $[\ldots]$ I think what our job is to get them to see the application of what they have done on their LLB, as it applies to practice...[so for instance] the reason you did easements and land law at university is that it is an interesting academic point as to when one exists or not, in practical terms it means you can or cannot get onto premises to carry out your business, and that's what you client wants to hear...So it is getting the students to understand the context in which they work (Director, for-profit legal education provider) 
The role of individuals already captured by the institutions of the City is, then, crucial in rendering education a way of effecting and sustaining these institutions. The second way in which the two-way relationship between postgraduate education and the City of London's institutional landscape becomes effective relates to how the formal dimensions of already existing institutions - specifically the regulatory environment of the City of London - has significant situating effects on training and in turn the practices new elites learn about (see also Hall 2008). In the case of finance, at the time this research was conducted, education focused on being designated 'competent' by the Financial Services Authority (FSA). On the 1 April 2013, the FSA was replaced by the Financial Conduct Authority and the Prudential Regulatory Authority with the latter having prime responsibility for determining the authorisation of individuals to practice as financiers in the UK. Whilst at the time of writing it is not yet clear how formal training requirements may change as a result of reform, in setting out its approach to supervision, the Prudential Regulation Authority states that employees must have 'appropriate experience and expertise' and that it 'expects firms to have a culture that supports their prudent management' (PRA 2013: 20), thereby echoing older discourses of maintaining an appropriate working culture (or set of cultural and social institutions) in London as designated by the Bank of England (see Pryke 1991).

In the case of law, the Solicitors Regulation Authority (SRA) controls the content and standards associated with the LPC and the traineeship period. It is, however, the flexibility offered by SRA controls that is most significant. The SRA sets a number of minimum standards and core content requirements, but allows education providers 
to determine how standards are met and to also define elective components of the education programmes, these elective components often consuming as much learning time as the core components. City law firms have exploited this flexibility by working with for-profit providers such as BPP and the College of Law to develop what has become known as the City LPC. This version of the LPC, designed exclusively for new recruits who have already secured employment at a City law firm, and in some cases even being firm-specific and tailored to cohorts of new elites all destined for the same firm, exploits the flexibility of the SRA's regulation in two main ways. At one level, content is made to reflect the kinds of legal work the City is famous for, including mergers and acquisitions and structured finance. Core components of the LPC which are at the periphery of interest to new elites in the City, work such as writing wills or dealing with property conveyance, are dealt with as speedily as possible, so as to fulfil the minimum requirements of the SRA. At another level, the primary pedagogic tool in the City LPC is the City case study. Either by taking well-documented landmark cases from the City or, when the LPC programme is exclusively for new elites destined for a single firm, by using case studies of recent deals completed by the firm and the standard forms and protocols used in the deal, learning is focussed upon 'doing law' in a way that is expected in the City. As one interviewee noted, the City LPC avoids:

you know, mismatch and I think what it's really all about is giving context to them so that they can see that what they are doing on the LPC, unlike when I did it when it was sort of going back to you know, pre-GCSE level, just learning a whole lot of stuff about matrimonial law etc., which has no relevance to, as far as could see to anything and I was right about that in terms of my future career...So I think you 
know, now [in the City LPC form] actually it is a valuable course, which is going to contribute to their career [in the City] (Professional support lawyer, City law firm)

In a recent review of legal education in England and Wales the SRA recommended that such tailored education becomes the norms rather than the exception in the future, the City LPC being cited as an example of the practice benefits that accrue from tailoring (see Solicitors Regulation Authority, 2013).

In both finance and law the regulatory mandating of forms of technical competence, and the structure regulation gives to education programmes, leads, therefore, to City-specific educational content being developed and an associated set of understandings of practice emerging, with certain meanings, competencies and technologies emphasised, and others simultaneously being de-emphasised (or even obscured). When coupled to the previously described way that postgraduate education is designed to mirror the already existing norms and cultures of the City by involving established elites in the education process, this impact of regulation appears to suggest a close relationship between education and the maintenance of the City's institutions. As such, education can be seen as being co-constitutive of the City's unique institutional regime; i.e., education is structured by the already existing institutional assemblage, and this structuring also ensures the active (re)production of the situated norms, cultures and practices that define the City's institutional advantage in international finance. We consider the implications of education's role in such a relationship in the final section of the paper. 


\section{Implications and Conclusions}

At one level this paper contributes to social scientific research on elites (Daloz, 2010; Savage and Williams, 2008) by revealing the hitherto neglected role of postgraduate education in inculcating early career elites into the legitimated practices of the City of London. At another level, we have demonstrated that postgraduate education is intimately tied to the institutional regime of financial centres, the education itself reflecting this regime and simultaneously helping to reproduce it through the instilling of particular practices - i.e., meanings, competencies and uses of technologies - in new members of a city's elite labour field. The connections between education and institutions are significant, we argue, because they are one of the mechanisms through which institutions, and in turn the widely documented variegated forms of financialized capitalism (Clark and Wójcik, 2007; Engelen et al., 2010; Dixon, 2011), get produced and sustained as education is used to inculcate new elites into London-specific practices.

Through our analysis, we make two important contributions. First, our findings reveal the value of extending work on the relationship between elites and education beyond the existing focus on the multiple forms of capital reproduced through educational background that have been shown to be important in securing entry into elite labour markets (Cook et al., 2012). Our research points to the importance of attending to the questions raised by Bourdieu's $(1990 ; 1996)$ wider analysis of practice, and by work on theories of practice more generally (Reckwitz, 2002; Røpke, 2009; Shove et al., 2012), about how education in elite occupations serves to (re)produce understandings of legitimate forms of practice. To do this, we have 
conceptualised postgraduate educational as a space in which individuals are recruited to practices through techniques designed to allow learning about the competencies and meanings that underlie the use of particular financial and legal instruments/materials. Specifically, we have outlined how through postgraduate education new elites develop explicit and procedural competencies, more tacit understandings about how to legitimately deploy a particular instrument, as well as understanding of the meanings associated with a legitimate performance. This learning leaves new elites predisposed to performing certain practices associated with the City of London's finance and producer service complex; in turn this making relocating to a different financial centre difficult because of the situated nature of these practices.

Second, our analysis contributes to wider debates concerning the institutional basis of city and regional economies. Whilst the institutional embedding of international financial centres has been well documented (Amin and Thrift, 1992, 1995; Augar, 2001), recent work beyond the case of financial centres has signalled the need to better analyse the mechanisms behind the construction and reproduction of institutions (Gertler, 2010; Martin, 2010; Storper, 2011). This paper suggests that postgraduate education is an important but hitherto overlooked mechanism through which the institutions of the City of London are rendered effective and reproduced. As such we go beyond characterising the institutional landscape of a financial centre, city or region, and suggest that postgraduate education is an exemplar of the kinds of mechanisms that need more analysis as part of work on the dynamics of institutional landscapes. In particular, our analysis implies that education might be 
an important site at which interventions aimed at changing problematic and institutionalised practices could occur, as was widely suggested to be necessary in financial centres in the wake of the 2007-8 financial crisis (see for example the Turner Review, 2009). Indeed, there is already evidence of such strategies being deployed: Goldman Sachs, for instance, is currently putting its investment bankers through compulsory day-long training simulations with the aim of embedding new cultures of responsibility and, in turn, changing practices in ways that reduce risks to clients and the bank in the future (The Economist, 2013).

The institutionally informed reading of postgraduate education we have developed here draws attention to the potential of such an approach, but also to the risk that such attempts will mirror previously unsuccessful efforts at changing practice through education, failure being a result of a tendency to focus on education in isolation without consideration of the wider institutional forces shaping the education. For example, following the crisis in corporate America in the early 2000s, several business schools placed a greater emphasis on corporate social responsibility and practical management issues within their curricula in order to better equip managers for 'real world' practice (Mintzberg, 2004; Pfeffer and Fong, 2004). However, there was widespread scepticism about whether changing the content of MBA courses would have an impact beyond the business school classroom, with critics arguing that a more wholesale rethinking of the business school and its relationship with its own institutional fields was required (Khurana, 2010; Starkey et al, 2004). Learning from this experience and our wider discussion of the relationship between practice, institutions and education suggests that any efforts to alter 
practice need to be cognisant of the important ways that education is shaped by as well as shapes the wider institutional contexts in which it operates. This means interventions via education may indeed help produce new institutionalised practice in the next generations of elites, but that such an effect will only be achieved if reforms simultaneously also target the 'hard' regulatory elements of institutions that shape education, and the cultures of the incumbent generations who might otherwise consider the practice of new elites illegitimate, this potentially impeding their legitimacy and career in the City. We make this claim as our analysis reveals a dialectal relationship between institutions and education; the former structuring the latter, whilst the latter also sustains (and might change) the former. The identified role of regulatory institutions in shaping education provides, then, the most actionable example of where reform could occur in institutional landscapes; changing regulations to enable/force the reform of educational content might help promote alternative practices and new taken for granted ways of acting in the City field. But, interventions in the harder to challenge practices of the incumbent generations would also be needed, this being a much more significant challenge.

In sum, this paper opens up the black boxes of both postgraduate education for elites, and the mechanisms of institutional effect, sustenance and disruption in ways that are important as part of agendas to, first, consider how elites influence contemporary economies (Daloz, 2010; Savage and Williams, 2008) and, second, analyse how financial centre, city and regional economies that affected by beneficial or problematic institutions might render those institutions more or less effective and sustained (Boschma and Frenken, 2006; Martin, 2010; Storper, 2011). 


\section{Acknowledgements}

Both authors acknowledge the support of the ESRC in funding the research reported here, through grants RES-000-22-2957 (for James Faulconbridge) and RES-061-250071 (for Sarah Hall).

\section{References}

Alvesson M. 2001: Knowledge work: ambiguity, image and identity Human Relations 54 863-886

Amin A, Thrift N J. 1995: Globalisation, institutional 'thickness' and the local economy, in Managing Cities: The New Urban Context Eds P Healey, S Cameron, S Davoudi, S Graham, A Madani-Pour (John Wiley \& Sons, Chichester) pp 91108

Anderson-Gough F, Grey C, Robson K. 2000: In the name of the client: The service ethic in two professional services firms Human Relations 53 1151-1174

Amin, A. and Thrift, N. 1992: Neo-Marshallian nodes in global networks. International Journal of Urban and Regional Research 16, 571-587.

Ashley, L. 2010: Making a difference? The use (and abuse) of diversity management at the UK's elite law firms. Work, Employment \& Society 24, 711727.

Augar, P. 2001: The death of gentlemanly capitalism: the rise and fall of London's investment banks: Penguin London. 
Beaverstock, J.V. 2005: Transnational elites in the city: British highly skilled migrants in New York Cityłs financial district. Journal of Ethnic Migration Studies 31, 245-268.

Beaverstock, J.V. and Hall, S. 2012: Competing for talent: global mobility, immitration and the City of London's labour market. Cambridge Journal of Regions, Economy and Society 5, 271-287

Beaverstock J V, Smith R, Taylor P J. 2000: World-city network: a new metageography Annals of the Association of American Geographers 90 123-134

Benner C. 2003: "Learning communities in a learning region: the soft infrastructure of cross-firm learning networks in Silicon Valley" Environment and Planning A 35 1809-1830

Boschma R A, Frenken K. 2006: Why is economic geography not an evolutionary science? Towards an evolutionary economic geography" Journal of Economic Geography 6 273-302

Bourdieu, P. 1990: The logic of practice: Stanford University Press.

Bourdieu, P. 1996: The State Nobility: Elite Schools in the Field of Power: Stanford University Press.

Boud, D. and Feletti, G. (eds) 1997: The challenge of problem-based learning. London: Hogan Page.

Brenner N, Peck J, Theodore N. 2010: Variegated neoliberalization: geographies, modalities, pathways Global Networks 10 182-222

Brown, P. and Hesketh, A. 2004: The Mismanagement of Talent: Employability and Jobs in the Knowledge Economy. Oxford: Oxford University Press. 
Calori R, Lubatkin M, Very P, Veiga J F. 1997: Modelling the origins of nationallybound administrative heritages: A historical institutional analysis of French and British firms Organization Science 8 681-696

Clark, G.L. 2011: Myopia and the global financial crisis. Dialogues in Human Geography 1, 4-25.

Clark G L, Mansfield D, Tickell A. 2002: Global finance and the German model: german corporations, market incentives, and the management of employersponsored pension instituions Transactions of the Instittue of British Geographers NS 27 91-110

Clark G L, Wójcik D. 2007: The geography of finance (Oxford University Press, Oxford)

Cook A, Faulconbridge J R, Muzio D. 2012: "London’s Legal Elite: recruitment through cultural capital and the reproduction of social exclusivity in City professional service fields" Environment and Planning A 44 1744-1762

Crouch C. 2005: Capitalist diversity and change. Recombinant governance and institutional entrepreneurs. (Oxford University Press, Oxford)

Daloz, J-P. 2010: The Sociology of elite distinction. Basingstoke: Palgrave.

Dixon A, 2011: "Varigated capitalism and the geography of finance: towards a common agenda" Progress in Human Geography 37 193-210

Economist, The. 2013: Reform school for bankers. The Economist October $5^{\text {th }}, 69$ 70.

Engelen E, Konings M, Fernandez R. 2010: Geographies of financialization in disarray: the Dutch case in comparative perspective" Economic Geography 86 $53-73$ 
Engelen E, Erturk I, Froud J, Johal S, Leaver A, Moran M, Williams K. 2012:

"Misrule of experts? The finanical crisis as elite debacle" Economy and Society $41360-382$

Faulconbridge J R, Engelen E, Hoyler M, Beaverstock J V. 2007: Analysing the Changing Landscape of European Financial Centres: the role of financial products and the case of Amsterdam Growth and Change 38 279-303

Faulconbridge, J.R. 2007: Exploring the role of professional associations in collective learning in London and New York $\Varangle s$ advertising and law professional service firm clusters. Environment and Planning A 39, 965-984.

Faulconbridge, J.R., Beaverstock, J.V., Hall, S. and Hewitson, A. 2009: The 'war for talent': the gatekeeper role of executive search firms in elite labour markets. Geoforum 40, 800-808.

Faulconbridge, J.R. and Muzio, D. 2009: The financialization of large law firms: situated discourses and practices of reorganization. Journal of Economic Geography 9, 641-661.

Faulconbridge J R, Muzio D. 2008: Organizational professionalism in globalizing law firms Work, Employment and Society 22 7-25

Faulconbridge J R, Muzio D, Cook A. 2012: Institutional legacies in TNCs and their management through training academies: the case of transnational law firms in Italy Global Networks 12 48-70

Froud, J., Johal, S., Leaver, A. and Williams, K. 2006: Financialization and strategy. Narrative and numbers. London and New York: Routledge.

Gertler M. 2010: Rules of the Game: The Place of Institutions in Regional Economic Change Regional Studies 44 1-15

Gherardi S. 2009: Practice? It's a Matter of Taste! Management Learning 40535 
Goldman Sachs. 2012: Why Goldman Sachs? Training and Orientation. http://www.goldmansachs.com/careers/why-goldman-sachs/training-andorientation/training-and-orientation-main-page.html, accessed 14/10/13

Grabher G. 1993: The embedded firm: On the socioeconomics of industrial networks (Routledge, London)

Hall P A, Soskice D. 2001: Varieties of capitalism. The institutional foundations of comparative advantage (Oxford University Press, Oxford)

Hall S, Appleyard L. 2009: City of Londong, City of Learning? Placing business education within the geographies of finance Journal of Econoic Geography 9: $597-617$

Hall S. 2008: Geographies of business education: MBA programmes, reflexive business schools and the cultural circuit of capital Transactions of the Institute of British Geographers 33: 27-41

Hall S. 2013: Business education and the reproduction of gendered cultures of work in the City of London Social Politics 20: 222-241

Hanlon G. 2004: Institutional Forms and Organizational Structures: Homology, Trust and Reputational Capital in Professional Service Firms Organization 11 187

Hatch C J. 2013: Competitiveness by Design: An Institutionalist Perspective on the Resurgence of a "Mature" Industry in a High-Wage Economy Economic Geography

Ho, K. 2009: Liquidated: an ethnography of Wall Street. Durham: Duke University Press. 
Jones, A. and Murphy, J.T. 2011: Theorizing practice in economic geography: Foundations, challenges and possibilities. Progress in Human Geography 35, 366-392.

Khurana, R. 2010: From higher aims to hired hands: the social transformation of American business schools and the unfulfilled promise of management as a profession. Princeton: Princeton University Press.

Kynaston, D. 2002: The City of London Volume 4: Club No More, 1945-2000 London: Pimlico.

Lee R, Clark G L, Pollard J, Leyshon A. 2009: The remit of financial geographybefore and after the crisis Journal of Economic Geography 9 723-747

Lewis, M. 2011: The big short: inside the doomsday machine. London: Penguin.

Leyshon, A. and Thrift, N. 1997: MoneySpace. Geographies of monetary transformations. London: Routledge.

Lounsbury, M. 2011: A tale of two cities: competing logics and practice variation in the professionalizing of mutual funds. Academy of Management Journal 50, 289-307.

MacKenzie, D A: 2003 An equation and its worlds. Social Studies of Science 33, 831-868

MacKenzie D A: 2006 An engine, not a how financial models shape markets (Cambridge, MA: Mit Press)

MacKinnon D. 2012: Beyond strategic coupling: reassessing the firm-region nexus in global production networks Journal of Economic Geography 12 227245 
MacKinnon D, Cumbers A, Pike A, Birch K, McMaster R. 2009: Evolution in economic geography: institutions, political economy, and adaptation Economic Geography 85 129-150

Martin, R. 2010: Roepke lecture in economic geography - Rethinking regional path dependence: beyond lock-in to evolution. Economic Geography 86, 1-27.

Mills, C Wright. 1956: The power elite (Oxford University Press: New York)

Mintzberg, H. 2004: Developing managers, not MBAs. London: FT Prentice Hall.

Pferrer, F. and Fong, C. 2004: The end of business schools? Less success than meets the eye. Academy of Management, Learning and Education 1, 78-95.

Pred A. 1981: Social reproduction and the time-geography of everyday life Geografiska Annaler 63, 5-22

PRA. 2013: The Prudential Regulatory Authority's approach to banking supervision, Bank of England Prudential Regulation Authority

Pryke, M. 1991: An international city going global: spatial change in the City of London. Environment and Planning D: Society and Space 9, 197-222.

Reckwitz, A. 2002: Toward a Theory of Social Practices: A Development in Culturalist Theorizing. European Journal of Social Theory 5, 243-263.

Røpke I. 2009: "Theories of practice--New inspiration for ecological economic studies on consumption" Ecological Economics 68 2490-2497

Sassen, S. 2012: Cities in a world economy (4th edition). London: Sage.

Savage, M. and Williams, K. 2008: Elites remembered in catpialism and forgotten by social sciences, In Savage M and Williams K (eds) Remembering Elites. Oxford: Blackwell.

Saxenian A. 1994 Regional advantage. Culture and competition in Silicon Valley and route 128 (Harvard University press, London) 
Schatzki T R. 1996 Social practices: A Wittgensteinian approach to human activity and the social (Cambridge University Press, Cambridge)

Shove, E. 2003: Comfort, cleanliness and convenience: the social organization of normality. Oxford \& New York: Berg publishers.

Shove E, Pantzar M, Watson M. 2012: The dynamics of social practice. Everyday life and how it changes (Sage, London)

Solicitors Regulation Authority. 2013: Training for tomorrow. Available at http://www.sra.org.uk/sra/policy/training-for-tomorrow/resources/policystatement.page [last accessed 15th November 2013]

Starkey, K., Hatchuel, A. and Tempest, S. 2004: Rethinking the business school. Journal of Management Studies 41, 1521-31.

Storper M. 2011: Why do regions develop and change? The challenge for geography and economics Journal of Economic Geography 11 333-346

Streeck W. 2009: Re-forming capitalism: Institutional change in the German political economy (Oxford University Press, Oxford)

Tett G. 2010: Fool's Gold (Abacus, London)

Thelen K A. 2004: How institutions evolve: The political economy of skills in Germany, Britain, the United States, and Japan (Cambridge Univ Pr)

Trubek, D.M., Dezalay, Y., Buchanan R and Davis, J.R. 1994: Global restructuring and the law: studies of the internationalization of legal fields and the creation of transnational arenas. Case Western reserve law review 44, 407-498.

Turner Review. 2009: A regulatory response to the global banking crisis. London: Financial Services Authority. 
Waters, J. 2007: Roundabout routes and sanctuary schools': the role of situated educational practices and habitus in the creation of transnational professionals. Global Networks 7, 477.

Wenger, E. 1998: Communities of practice: learning meaning and identity. Cambridge: Cambridge University Press.

Wilk R, 2002: Consumption, human needs, and global environmental change Global Environmental Change 12 5-13

Zald M N, Lounsbury M, 2010: The wizards of Oz: Towards an institutional approach to elites, expertise and command posts Organization Studies 31 963996

Zaloom, K. 2006: Out of the pits: traders and technology from Chicago to London. Chicago: Chicago University press. 
Table 1: Firm-based postgraduate education required when entering the financial and legal service fields in the City of London

\begin{tabular}{|c|c|c|}
\hline $\begin{array}{l}\text { Component of } \\
\text { education }\end{array}$ & Finance & Law \\
\hline $\begin{array}{l}\text { Training to gain } \\
\text { regulatory approval to } \\
\text { practice in the City }\end{array}$ & $\begin{array}{l}\text { 'Approved person' status } \\
\text { gained by completing } \\
\text { courses delivered by for- } \\
\text { profit providers }\end{array}$ & $\begin{array}{l}\text { The Legal Practice } \\
\text { Certificate gained by } \\
\text { completing the City LPC } \\
\text { (Legal Practice Course) } \\
\text { delivered by for-profit } \\
\text { providers; followed by } \\
\text { traineeship at a law firm } \\
\text { and completion of } \\
\text { mandated learning } \\
\text { exercises }\end{array}$ \\
\hline Corporate training & $\begin{array}{l}\text { Understanding of } \\
\text { employing firm's best } \\
\text { practice gained through } \\
\text { seminars delivered by in- } \\
\text { house training teams, } \\
\text { senior employees or } \\
\text { contracted-in providers }\end{array}$ & $\begin{array}{l}\text { Understanding of } \\
\text { employing firm's best } \\
\text { practice gained through } \\
\text { academy programmes for } \\
\text { new recruits, seminars } \\
\text { delivered by in-house } \\
\text { training teams, senior } \\
\text { employees or contracted- } \\
\text { in providers }\end{array}$ \\
\hline $\begin{array}{l}\text { Continuing professional } \\
\text { development }\end{array}$ & $\begin{array}{l}\text { Voluntary continuing } \\
\text { professional } \\
\text { development provided } \\
\text { by for-profit financial } \\
\text { education firms }\end{array}$ & $\begin{array}{l}\text { Mandated hours of } \\
\text { continuing professional } \\
\text { development delivered } \\
\text { in-house by employing } \\
\text { firms and by for-profit } \\
\text { providers in the City }\end{array}$ \\
\hline
\end{tabular}

Source: Authors' fieldwork 